\title{
Inflation and the public investment: Growth relationship in Vietnam
}

\author{
NGUYEN VAN BON ${ }^{a}$ \\ a Unive Sai Gon University
}

\begin{abstract}
ART I C L E I N F O A B S TRACT
Received 24 May 2017

Revised 19 Oct, 2017

Accepted 1 Jan. 2018

Available online

12 January 2018

JEL classifications:

E42; F43; H54

\section{KEYWORDS}

Public capital spending positively contributes to economic growth and development in many countries worldwide. However, questions concerning the importance of inflation in the public investmentgrowth relationship are of great interest. This study examines the role of inflation in the public investment-growth relationship in Vietnam using the two-step GMM Arellano-Bond estimators for a balanced panel data of 52 provinces during the period of 2005-2014. More interesting are the empirical findings. First, inflation significantly increases the volume of public capital spending. Second, public investment and inflation enhance economic growth, but their interaction term impedes it. Third, private investment, government recurrent expenditure, and trade openness are the significant determinants of growth. These findings suggest some important policy implications related to public capital spending and inflation in developing countries, specifically the Vietnam government.
\end{abstract}

Public investment

Inflation

Economic growth

GMM Arellano-Bond

estimators

Provinces in Vietnam

\footnotetext{
a Email: bonvnguyen@yahoo.com
} 


\section{Introduction}

Many governments worldwide increasingly invest in infrastructure, education, and health through public investment projects to enhance economic growth, create more employments, and stabilize social security. Thus, public investment crucially contributes to economic activities. However, public capital spending may adversely affect economic development, which originates from two main causes: public capital spending reduces private investment due to crowding-out effect, and inefficient public investment projects do not bring the expected benefits to people, and lower the productivity of public capital.

In Vietnam, public capital spending is a primary derivative of infrastructure development for the economy. During the transition process to a market-oriented economy, the Vietnam government continuously implements the expansionary fiscal policy by increasing public capital spending with expectation that public investment positively promotes economic activities, enhances the productivity of the economy, and stimulates investment capital from private sector. However, the level of public investment capital of the Vietnam government often fluctuates, which strongly depends on the situation of the economy. In the case of economic recession and high unemployment, the level of public investment capital increases sharply, but it will be cut down immediately if the economy grows rapidly with high inflation.

The model of economic development in Vietnam is inherently based on investment capital so far (To, 2012). The capital/GDP ratio increases up $41.9 \%$ in 2010 from $35.4 \%$ in 2001. The average capital/GDP ratio over the 2001-2010 period is approximately $41 \%$, a relatively high increase compared with the 1991-2010 period, which is ranked the highest in East and Southeast Asia. In 10 years, the capital volume of foreign investment sector, private sector and public sector increased by 5.1, 3.5, and 2.5 times, respectively. In regard to the structure, however, the public sector still accounts for the largest proportion in the total investment of the whole society. In the period of 2000-2009, investment by public sector in economic sectors accounted for a high proportion (73\% of public total investment) while its investment in social sectors, which has direct impacts on human development, decreased from $17.6 \%$ in 2000 to $15.2 \%$ in 2009. Accordingly, from 2005 to 2010, investment by public investment in agriculture decreased from $7.14 \%$ to $5.86 \%$, in science, education and training from $6.75 \%$ to $5.55 \%$, and in healthcare and social subsidy from $3.37 \%$ to $2.7 \%$. Contrarily, public capital spending in state management, public security, national defense, and political unions increased from $8.29 \%$ in 2005 to $9.67 \%$ in 2010 .

In short, the statistical data show that investment by public sector in Vietnam still focuses on sectors in which private sector is strong and willing to invest while its investment in the sectors to develop human resources (human capital) is not commensurate. It seems inappropriate with the fundamental principles of public investment that public sector has 
to set up the basis for the society's development and the economy's growth and undertake low profit, large capital projects which the private sector refuses and leave other projects which the private sector can do better.

Motivated by the fact that Vietnam is a fast-growing economy with a relatively high level of public investment, we shed a new light on taking account of inflation for the understanding of public investment-growth relationship in Vietnam. Most of the related literature on public investment and inflation has either examined the relationship between public investment and growth (Rodríguez-Pose et al., 2012; Abiad et al., 2016; Andrade \& Duarte, 2016) or the relationship between inflation and growth (Vinayagathasan, 2013; Baglan \& Yoldas, 2014; Bittencourt et al., 2015; Thanh, 2015). No existing papers estimate the effects of public investment, inflation, and their interaction term on growth. To investigate the role of inflation in the public investment-growth relationship in Vietnam for a balanced panel data of 52 provinces over the 2005-2014 period, we first use the two-step system GMM Arellano-Bond estimator (S-GMM) to estimate the impact of inflation on public investment. Then, we examine the effects of public investment, inflation, and their interaction term on growth. In particular, the robustness of the estimation will be checked by the two-step difference GMM Arellano-Bond estimator (D-GMM).

Given the relevance of this topic, the influence of inflation on the public investmentgrowth relationship is theoretically analyzed and modeled by Ferreira (1999). Ferreira arguably states that government investment is financed by inflation tax, and has a spillover effect on the macro variables of the model. When government investment increases, national income increases. In particular, “... money creation finances public investment, and thus increases the growth rate of output and consumption and therefore improves consumer's utility." (Ferreira, 1999, page 553). It implies an increase in inflation leads to an increase in public investment, which has a significant effect on economic growth. Accordingly, the analytical framework will be definitely developed to form empirical equations in Section 3.

The paper is structured in the following way. Section 2 takes a look into the literature, which reviews the public investment-growth relationship as well as the inflation-growth relationship. Section 3 develops an analytical framework to form the empirical equation. The model specification and research data are presented in Section 4 that specially emphasizes the characteristic and appropriateness of the two-step GMM Arellano-Bond estimators. Section 5 is the empirical results that consist of S-GMM estimates and the robustness check by D-GMM. The final section concludes and suggests some important policy implications.

\section{Literature review}

\section{The public investment-growth relationship}

Public capital spending plays an important role in economic development and activities because it positively contributes to improving infrastructure and enhancing accumulation 
of human capital. Khan et al. (2001) report public investment has a significantly positive net impact on GDP in Pakistan over the period of 1964-1997 by using OLS estimation. Meanwhile, Mittnik and Neumann (2001) argue public capital is a crucial input of production and positively promotes economic activities of private sector while the way public sector being financed can be detrimental to this sector's development. Indeed, by using VAR model for quarterly time series data of six developed countries, Mittnik and Neumann (2001) show public investment is a source of endogenous growth. Similarly, Milbourne et al. (2003) use the extension Solow-Swan growth model developed by Mankiw, Romer and Weil for 74 countries and find the effect of public investment on economic growth is not significant for the steady state model while it is significantly positive for the transition model. In the same vein, by using 3SLS estimation and time series data during 1981-2003, Murty and Soumya (2007) show a sustained increase in public capital spending in infrastructure in India, financed by commercial banks, positively affects economic growth. More recently, Andrade and Duarte (2016) employ ADL estimations proposed by Krolzig-Hendry-Doornik to investigate the effect of public investment on Portuguese economic growth over the period of 1960-2013. The estimated results show public investment has a significantly positive effect on economic growth.

However, government decisions on the distribution of public capital among regions are of great political concern among policymakers (Kataoka, 2005). Ramirez and Nazmi (2003) suggest scarce public sources should be used for contribution to new human capital (via education) and the maintenance of existing human capital (through healthcare). Using the seemingly unrelated (SUR) procedure for nine major Latin American countries during the period of 1983-1993, Ramirez and Nazmi (2003) show public investment spending positively contributes to economic growth. Kataoka (2005), who employs fixed effects estimation for a panel data of 47 prefectures in Japan during the period of 1955-2000, concludes public investment is a policy tool for adjusting income distribution and boosting economic growth in regions. In addition, policies of fiscal adjustment towards decreasing government investment may reduce aggregate investment, negatively affect economic growth and even impede the adjustment in the future (Belloc \& Vertova, 2006). The paper by Belloc and Vertova (2006) which uses VECM model for seven highly indebted lowincome countries over the period of 1970-1999 finds a significantly positive relation between public investment and output in these countries.

In addition, some theoretical models are developed to examine the effect of public capital spending on economic growth. Rodríguez-Pose et al. (2012) develop a model which captures not just the effect of public capital spending in Greek prefectures, but also the spillovers associated with the existence of externalities from neighboring regions. The results from testing this model by the estimation methods of fixed effects and pooled OLS for a panel data of 51 prefectures in Greek during the period of 1978-2007 show a significantly positive effect of public investment on regional economic growth in long run. Similarly, Abiad et al. (2016) uses model simulations to investigate the macroeconomic effects of public investment 
for a sample of 17 OECD economies over the period of 1985-2013. The study finds increased public investment promotes economic growth in both short term and long term, crowds in private investment, and reduces unemployment.

\section{The inflation-growth relationship}

One of the main goals of monetary authorities is to maintain the stability of price level which in turn creates the sound macro-environment to enhance the economic growth. So, the policymakers should understand more clearly the relationship between inflation and growth to design, formulate and implement reasonable policies. In regard with the relevance of this topic, most of related literature shows a non-linear relationship between inflation and growth whilst some find a negative link. In particular, Mallik and Chowdhury (2001) find a long-term positive relationship between inflation and growth rate in four South Asian nations over the period of 1957-1997. Conversely, Gillman et al. (2004) report a negative inflation-growth relationship for a panel dataset of OECD and APEC nations during the period of 1961-1997. Meanwhile, Bittencourt (2012) shows inflation negatively affects economic growth in four Latin American countries from 1970 to 2007. Similarly, Bittencourt et al. (2015) confirm a negative impact of inflation on economic growth in 15 subSaharan African countries (SADC) during the period of 1980-2009.

For the nonlinear relationship between inflation and growth, all studies are carried for samples of countries except Risso and Carrera (2009) find the threshold value of inflation $9 \%$ for Mexican economy. The threshold values of inflation in developing countries (7-11\%) are relatively higher than those in developed countries (1-3\%) (Khan \& Senhadji, 2001; López-Villavicencio \& Mignon, 2011). Most of these papers confirm the inflation-growth relationship is significantly negative if inflation is above the threshold value while it is insignificant (Vaona \& Schiavo, 2007; Risso \& Carrera, 2009; Kremer et al., 2013; Vinayagathasan, 2013) or significantly positive (Bick, 2010; Omay \& Öznur Kan, 2010; Thanh, 2015) if inflation is below this threshold value.

To summarize, there is no existing studies on the role of inflation in the public investment-growth relationship. It is a research gap to which this paper addresses to contribute to the related literature.

\section{Analytical framework}

Supposing the economy has two major inputs including domestic capital stock (public and private investment capital) and working force. The analytical framework starts with the traditional aggregate production function Cobb-Douglas as follows:

$$
Y=A G^{\alpha} P^{\beta} L^{1-\alpha-\beta}, 0<\alpha<1
$$

where $Y$ is real gross domestic product (GDP); $G$ and $P$ are public investment capital and private investment capital respectively; $L$ is the number of workers employed; $A$ is the total factor productivity (TFP); $a, \beta$, and $1-a-\beta$ are the production elasticities. 
We transfer equation (1) into the log-linear form:

$$
\log Y=\log A+\alpha \log G+\beta \log P+(1-\alpha-\beta) \log L
$$

We write equation (2) in growth form with a time series specification:

$Y_{i, t}=A_{i, t}+\alpha G_{i, t}+\beta P_{i, t}+(1-\alpha-\beta) L_{i, t}$

According to the theory of endogenous growth (Romer, 1986; Lucas, 1988), the total factor productivity, capital stock and working force are endogenous variables. For convenience Eq. (3) is rewritten as follows::

$$
Y_{i, t}=A_{i, t}+\alpha_{1} G I N_{i, t}+\alpha_{2} P I N_{i, t}+\alpha_{3} L A B_{i, t}
$$

where GIN, PIN, and $L A B$ are public investment, private investment, and labor force respectively. Public investment has a positive impact on economic growth because it contributes to improving infrastructure and enhancing accumulation of human capital. Blankenau and Simpson (2004) confirm the government plays a crucial role in accumulation of human capital by public spending in education. Thus, public investment affects the longrun economic growth.

There are many factors which have impacts on the total factor productivity (TFP). In this study, the determinants of TFP are determined as follows:

$$
A_{i, t}=\beta_{0}+\beta_{1} I N F_{i, t}+\beta_{2} G E X_{i, t}+\beta_{3} T E L_{i, t}+\beta_{4} O P E_{i, t}+\varepsilon_{i, t}
$$

where INF, GEX, TEL, OPE are inflation, recurrent expenditure, infrastructure development, and trade openness, respectively. The consumer price index has important effects on growth (Friedman, 1977). Its impact on economic growth may be positive or negative. The positive impact comes from potential benefits of this index in improving the saving and investment while the negative impact is detrimental to the economy because it increases the transaction costs of economic activities (Jin \& Zou, 2005). Meanwhile, the composition of recurrent expenditure is diversified, including expenses for administration and costs of operations and maintenance for education, science, and technology. Bose et al. (2007) argue in the growth theory that education, science, technology, environment, and healthcare are important factors for the economic prosperity in future. In the same vein, the infrastructure development can be measured in some different ways such as the length of high way per square kilometer (Du, Lu \& Tao, 2008), the length of railway (Kuzmina et al., 2014) or the fixed telephone subscriptions per 100 people (Bissoon, 2012). It is proxy for development of infrastructure which has an influence on economic growth in a country (Asiedu, 2002). Finally, the theory of endogenous growth indicates the improved activities of imports and exports have a positive impact on economic growth (Romer, 1986; Lucas, 1988). The trade liberalization leads to highly absorb technological progress and exchange more imported goods and services between countries and so promotes the economic growth (Grossman \& Helpman, 1991; Barro \& Sala-i-Martin, 2004).

We substitute equation (5) into equation (4): 


$$
Y_{i, t}=\beta_{0}+\beta_{1} G I N_{i, t}+\beta_{2} I N F_{i, t}+\beta_{3} P I N_{i, t}+\beta_{4} G E X_{i, t}+\beta_{5} L A B_{i, t}+\beta_{6} T E L_{i, t}+\beta_{7} O P E_{i, t}+\varepsilon_{i, t}
$$

According to Barro et al. (1991) and Tondl (2001), due to the conditional convergence of per capita income in the long term between the countries, the initial level of per capita income (the first lag of GDP per capita) has a negative impact on economic growth. This variable is added in the equation (6) as follows:

$$
\begin{gathered}
Y_{i, t}-Y_{i, t-1}=\beta_{0}+\beta_{1} Y_{i, t-1}+\beta_{2} G I N_{i, t}+\beta_{3} I N F_{i, t}+\beta_{4} P I N_{i, t}+\beta_{5} G E X_{i, t}+\beta_{6} L A B_{i, t}+ \\
\beta_{7} T E L_{i, t}+\beta_{8} O P E_{i, t}+\varepsilon_{i, t}
\end{gathered}
$$

In particular, an increase in inflation can lead to an increase in public capital spending, which may significantl affect economic growth (Ferreira, 1999). Therefore, the interaction term between public investment and inflation is corporated in the final empirical model:

$$
\begin{aligned}
Y_{i, t}-Y_{i, t-1}= & \beta_{0}+\beta_{1} Y_{i, t-1}+\beta_{2} G I N_{i, t}+\beta_{3} I N F_{i, t}+\beta_{4} G I N_{i, t} \times I N F_{i, t}+\beta_{5} P I N_{i, t}+ \\
& \beta_{6} G E X_{i, t}+\beta_{7} L A B_{i, t}+\beta_{8} T E L_{i, t}+\beta_{9} O P E_{i, t}+\eta_{i}+\xi_{i, t}
\end{aligned}
$$

where $\varepsilon_{i t}=\eta_{i}+\xi_{i, t}$

\section{Model specification and research data}

\subsection{Model specification}

Based on the analytic framework, the empirical equation is as follows:

$$
\begin{aligned}
& Y_{i t}-Y_{i t-1}=\beta_{0}+\beta_{1} Y_{i t-1}+\beta_{2} G I N_{i t}+\beta_{3} I N F_{i t}+\beta_{4} G I N_{i t} \times I N F_{i t}+X_{i t} \beta_{5}^{\prime}+\eta_{i}+\xi_{i t} \\
& \text { or } \\
& Y_{i t}=\beta_{0}+\beta_{1}^{\prime} Y_{i t-1}+\beta_{2} G I N_{i t}+\beta_{3} I N F_{i t}+\beta_{4} G I N_{i t} \times I N F_{i t}+X_{i t} \beta_{5}^{\prime}+\eta_{i}+\xi_{i t}
\end{aligned}
$$

where subscript $\mathrm{i}$ and $\mathrm{t}$ are the province and time index, respectively and $\beta_{1}^{\prime}=1+\beta_{1}$. $\mathrm{Y}_{\text {it }}$ is the natural logarithm of real GDP per capita, $\mathrm{Y}_{\mathrm{it}-1}$ is proxy for initial level of per capita income, GIN $\mathrm{Gi}_{\text {it }}$ is public investment, and $\mathrm{INF}_{\text {it }}$ is the natural logarithm of consumer price index, proxy for inflation. $\mathrm{X}_{\mathrm{it}}$ is a set of control variables (private investment, government current expenditure, labor force, infrastructure, and trade openness); $\eta_{i}$ is an unobserved time-invariant, province-specific effect and $\zeta_{i t}$ is an observation-specific error term. The coefficient $\beta_{1}^{\prime}$ in Eq. (10) will be positive if it is conditional convergent and negative if divergent (Barro et al., 1991; Tondl, 2001).

For Eq. (10), we use the general method of moments (GMM) Arellano and Bond (1991) estimators first proposed by Holtz-Eakin et al. (1988). Eq. (9) is a dynamic model, so we take the first difference to remove province-specific effects. Then, the regressors in first difference are used as instrumented by their lags under the assumption that time-varying disturbances in the original models are not serially correlated (Judson and Owen, 1999). This strategy is D-GMM, which is well-known to be able to deal with simultaneity biases in regressions.

Eq. (10) can be transformed into an equation in first difference as follows: 


$$
\begin{gathered}
Y_{i t}-Y_{i t-1}=\beta_{1}^{\prime}\left(Y_{i t-1}-Y_{i t-2}\right)+\beta_{2}\left(G I N_{i t}-G I N_{i t-1}\right)+\beta_{3}\left(I N F_{i t}-I N F_{i t-1}\right)+\beta_{4}\left(G I N_{i t} \times\right. \\
\left.I N F_{i t}-G I N_{i t-1} \times I N F_{i t-1}\right)+\left(X_{i t}-X_{i t-1}\right) \beta_{5}^{\prime}+\left(\xi_{i t}-\xi_{i t-1}\right)
\end{gathered}
$$

In case variables are persistent, their past values show little information about their future changes, making their lags become weak instruments for their differenced series. Thus, Arellano and Bover (1995) suggest a combination of Eq. (10) and Eq. (11) to form a system of two equations, an equation in difference series instrumented by lagged levels, and an equation in levels instrumented by lagged differences to which GMM is applied. It is known as S-GMM, a strategy which is able to enhance the efficiency via its reduction in biases and solving the weak instruments problem in D-GMM (Blundell \& Bond, 1998). The consistency of S-GMM is obviously based on the assumptions that the error terms are uncorrelated, the instruments are valid, and the changes in additional instruments are not correlated with province-fixed effects.

In comparison with the one-step GMM estimators, the two-step GMM estimators are more asymptotically efficient. However, the application of the two-step GMM estimators in small samples, as in our study, has some problems (Roodman, 2006). These problems are set up by the proliferation of instruments, which quadratically increase as the time dimension increases. It can cause the number of instruments to be very large relative to the number of provinces. To avoid it, the rule of thumb should be applied to maintain the number of instruments less than or equal to the number of panel units (Roodman, 2006).

The validity of instruments in S-GMM and D-GMM is assessed through Sargan statistic, Hansen statistic and Arellano-Bond statistic. The Sargan and Hansen tests with null hypothesis $\mathrm{H}_{0}$ : the instrument is strictly exogenous, which means that it does not correlate with errors. Thus, the p-value of Sargan statistic and Hansen statistic is as big as possible. The Arellano-Bond test is used to detect the autocorrelation of errors in first difference. Thus, the test result of first autocorrelation of errors, $\mathrm{AR}(1)$ is ignored while the second autocorrelation of errors, $\operatorname{AR}(2)$, is tested on the first difference series of errors to detect the phenomenon of first autocorrelation of errors, $\operatorname{AR}(1)$.

\subsection{Research data}

Cross-sections and time series are extracted to accommodate the balanced panel data of 52 provinces $^{2}$ over the period of 2005-2014 from General Statistics Office of Vietnam (GSO). There are 11 out of 63 provinces to be eliminated due to data not available. We define and calculate the variables as follows:

- Real GDP per capita (GDP): a real gross domestic product of a province, proxy

\footnotetext{
${ }^{2}$ Ha Noi, Vinh Phuc, Bac Ninh, Quang Ninh, Hai Duong, Hai Phong, Hung Yen, Thai Binh, Ha Nam, Nam Dinh, Ninh Binh, Cao Bang, Lao Cai, Yen Bai, Thai Nguyen, Lang Son, Bac Giang, Phu Tho, Son La, Hoa Binh, Thanh Hoa, Nghe An, Ha Tinh, Quang Tri, Thua Thien-Hue, Da Nang, Quang Nam, Quang Ngai, Binh Dinh, Phu Yen, Khanh Hoa, Ninh Thuan, Binh Thuan, Dak Nong, Lam Dong, Binh Phuoc, Tay Ninh, Binh Duong, Dong Nai, Ba Ria-Vung Tau, Ho Chi Minh City, Long An, Tien Giang, Ben Tre, Tra Vinh, Vinh Long, An Giang, Kien Giang, Can Tho, Hau Giang, Bac Lieu, and Ca Mau.
} 
for economic growth of a province. This variable is used in form of natural logarithm.

- Government investment (GIN): public investment capital in a province (\% GDP).

- Consumer price index (INF): a proxy for inflation of a province. It is used in form of natural logarithm.

- Private investment (PIN): private investment capital in a province (\% GDP).

- Public recurrent expenditure (GEX): the current expenditure of a province (\% GDP).

- Labor force (LAB): a ratio between working age people (15-64) and total population of a province $(\%)$.

- Infrastructure (TEL): the number of telephone lines per 100 people. It is proxy for development of infrastructure in a province. It is used in form of natural logarithm.

- $\quad$ Trade openness (OPE): a ratio between sum of exports and imports and GDP (\%). It is proxy for the policy of openness of a province.

The statistical description of variables is presented in Table 1.

\section{Table 1}

Statistical description

\begin{tabular}{lccccc}
\hline Variable & Obs & Mean & Std. Dev. & Min & Max \\
\hline GDP per capita (VND millions/year) & 520 & 25.329 & 31.962 & 7.262 & 298.691 \\
Public investment (\% GDP) & 520 & 6.446 & 4.488 & 0.831 & 27.274 \\
Consumer price index & 520 & 110.462 & 6.325 & 99.2 & 140 \\
Private investment (\% GDP) & 520 & 23.111 & 9.586 & 0.731 & 72.830 \\
Public current expenditure (\% GDP) & 520 & 12.379 & 6.983 & 1.021 & 51.583 \\
Labor force (\% population) & 520 & 55.765 & 4.890 & 36.621 & 67.396 \\
Telephone lines per 100 people & 520 & 1816.343 & 8401.272 & 29.6 & 85215 \\
Trade openness (\% GDP) & 520 & 87.820 & 117.983 & 1.052 & 894.168 \\
\hline
\end{tabular}

The matrix of correlation coefficients for variables is presented in Table 2. Public investment, inflation, private investment, government current expenditure, and force labor are negatively linked with whilst infrastructure and trade openness is positively connected to economic growth at least significance of $5 \%$ level. All correlation coefficients between explanation variables are lower than 0.8 , which helps to eliminate the possibility of colinearity between these variables. 
Table 2

Matrix of correlation coefficients

\begin{tabular}{|c|c|c|c|c|c|c|c|c|}
\hline & GDP & GIN & INF & PIN & GEX & LAB & TELE & OPE \\
\hline GDP & 1.000 & & & & & & & \\
\hline GIN & $-.349^{* * *}$ & 1.000 & & & & & & \\
\hline INF & $-.116^{* * *}$ & $.082^{*}$ & 1.000 & & & & & \\
\hline PIN & $-.251^{* \star *}$ & $.204^{* * \star}$ & .047 & 1.000 & & & & \\
\hline GEX & $-.588^{* * \star}$ & $.546^{* \star *}$ & .037 & $.152^{* * *}$ & 1.000 & & & \\
\hline LAB & $-.096^{* *}$ & $-.169^{* * *}$ & -.040 & $.117^{* \star *}$ & $.262^{* * *}$ & 1.000 & & \\
\hline TEL & $.541^{\star * \star}$ & $-.214^{\star \star \star}$ & .011 & .022 & $-.282^{\star * *}$ & $.131^{* * *}$ & 1.000 & \\
\hline OPE & $.415^{\star \star *}$ & $-.175^{\star \star \star}$ & -.025 & -.053 & $-.345^{* \star *}$ & $.091^{* *}$ & $.243^{* * *}$ & 1.000 \\
\hline
\end{tabular}

Note: ${ }^{* * *},{ }^{* *}$ and ${ }^{*}$ denote significance at $1 \%, 5 \%$ and $10 \%$ respectively

Source: Stata software

\section{Results and discussion}

\subsection{S-GMM estimates}

\section{The appropriateness of S-GMM}

The main results derived by S-GMM are reported in Table 4. The signs of estimated coefficients, which show the effects of public investment, inflation, and private investment on growth, are opposite to those of correlation coefficients given in Table 2. It implies that there exists an endogenous phenomenon between the regressand and regressors. Hence, SGMM with instrumental variables seems to be appropriate for this empirical model.

In the estimation procedure, we detect inflation and private investment are endogenous, so we use the lags of these variables as instrumented and the remaining variables (public investment, government recurrent expenditure, labor force, infrastructure, and trade openness) as instruments. In order to assess the validity of these instruments and the serial auto-correlation of residuals, we performs the Sargan and Hansen tests (test of overidentifying restrictions with the null hypothesis "the instruments as a group are exogenous") as well as the Arellano-Bond test for serial correlation AR(2), which is applied to the difference residuals to purge the unobserved and perfectly auto-correlated. In Table 4 the Hansen and Sargan tests for over-identifying restrictions indicate that the instrument set turns out valid. The Arellano-Bond AR(2) tests accept the hypothesis of no autocorrelation of the second order. In addition, the number of instruments is less than or equal to the number of provinces. Therefore, these results support our model specification. 


\section{Inflation and public investment}

In his arguments, Ferreira arguably states that public investment is financed by inflation tax (through money creation) (Ferreira, 1999, page 553). In order to assess the impact of inflation on public investment, the following empirical equation is used:

$$
G I N_{i t}=\alpha_{0}+\alpha_{1} G I N_{i t-1}+\alpha_{2} I N F_{i t}+Z_{i t} \alpha_{j}^{\prime}+\eta_{i}+\xi_{i t}
$$

where $Z_{i t}$ is a set of control variables (private investment, government current expenditure, economic growth, labor force, infrastructure, and trade openness).

\section{Table 3}

Inflation and public investment: 2005-2014

Dependent variable: Public investment

\begin{tabular}{|c|c|c|}
\hline & S-GMM & D-GMM \\
\hline \multirow[t]{2}{*}{ Public investment (-1) } & $0.430^{* * *}$ & $0.326^{* * *}$ \\
\hline & $(0.072)$ & $(0.063)$ \\
\hline \multirow[t]{2}{*}{ Inflation } & $0.012^{* *}$ & $0.041^{* *}$ \\
\hline & $(0.005)$ & $(0.016)$ \\
\hline \multirow[t]{2}{*}{ Private investment } & $0.085^{* *}$ & $0.285^{* * *}$ \\
\hline & $(0.040)$ & $(0.053)$ \\
\hline \multirow[t]{2}{*}{ Recurrent expenditure } & $0.177^{* * *}$ & $0.362^{* * *}$ \\
\hline & $(0.040)$ & $(0.065)$ \\
\hline \multirow[t]{2}{*}{ Economic growth } & -0.004 & -0.011 \\
\hline & $(0.003)$ & $(0.008)$ \\
\hline \multirow[t]{2}{*}{ Labor force } & $-0.156^{* * *}$ & 0.017 \\
\hline & $(0.048)$ & $(0.087)$ \\
\hline \multirow[t]{2}{*}{ Infrastructure } & 0.0027 & -0.0008 \\
\hline & $(0.002)$ & $(0.002)$ \\
\hline \multirow[t]{2}{*}{ Trade openness } & 0.001 & -0.001 \\
\hline & $(0.0008)$ & $(0.003)$ \\
\hline Instrument & 22 & 20 \\
\hline Province/Observation & $52 / 364$ & $52 / 416$ \\
\hline Sargan test & 0.164 & 0.406 \\
\hline Hansen test & 0.422 & 0.594 \\
\hline $\mathrm{AR}(2)$ test & 0.317 & 0.306 \\
\hline
\end{tabular}

Note: ${ }^{* * *}{ }^{* *}$ and $*$ denote significance at $1 \%, 5 \%$ and $10 \%$ respectively

Source: Stata software 
The estimated results are presented in the Table 3. Inflation increases public investment. In fact, inflation can distort the public capital spending in infrastructure (Hefner and Burson, 1990). When inflation increases, ceteris-paribus, the government has to spend more investment capital to accomplish a given public project. It implies higher inflation leads to a larger volume of public investment capital.

The estimated results also show private investment and recurrent expenditure have significantly positive effects while labor force has a negative impact on public investment.

\section{Public investment, inflation and growth}

The estimated results in the Table 4 show that: (i) the first lag of growth significantly and positively correlates with economic growth in level, confirming the conditional convergence of per capita income among provinces in the long term (Barro et al., 1991; Tondl, 2001); (ii) public investment and inflation significantly enhance economic growth, but their interaction term impedes it; and (iii) private investment and trade openness have significantly positive effects whilst government recurrent expenditure has a significantly negative impact on growth.

The positive effect of public investment on growth is obviously consistent with Khan et al. (2001), Mittnik and Neumann (2001), Milbourne et al. (2003), Ramirez and Nazmi (2003), Kataoka (2005), Belloc and Vertova (2006), Rodríguez-Pose et al. (2012), and Abiad et al. (2016). In recent years, public capital spending in provinces of Vietnam is largely invested in infrastructure development to serve for local economic activities, in building schools to improve quality of education, and in building hospitals to improve the quality of healthcare. Thus, public investment in Vietnam positively contributes to economic growth through providing infrastructure for economic activities and significantly enhances accumulation of human capital through improving education and health. Meanwhile, the positive impact of inflation on growth confirms the prior finding in Mallik and Chowdhury (2001) that its positive contribution is to improve the saving and investment (Jin \& Zou, 2005).

Contrary to public investment and inflation, their interaction term reduces growth. We believe that the negative impact of interaction term can mainly come from an increase in inflation. One hand, a moderate increase in inflation positively promotes economic growth (as shown in Table 4). On the other hand, cetaris-paribus, it leads to a larger volume of public capital spending (as shown in Table 3). To achieve the same benefits for a given public investment project, the volume of public investment in case of high inflation is larger than that in case of low inflation. Hence, under high inflation, the volume of public investment is higher for the same utility, which is detrimental to economic activities and growth.

The public recurrent expenditure, a nonproductive expenditure, is basically local government spending on administration such as wages, salaries, interest on loans, maintenance cost... which does not result in the creation or acquisition of fixed assets. Bleaney et al. (2001) indicate the negative but insignificant impact of recurrent expenditure on growth. 
In the models of economic growth, private investment is a crucially endogenous input to contribute to output. Ghura (1997) provides empirical evidence to confirm the positive role of private investment in the economy. Meanwhile, the positive impact of trade openness on growth has been found in Yanikkaya (2003), and Makki and Somwaru (2004).

\section{Table 4}

Public investment, inflation and growth: 2005-2014

Dependent variable: Growth

\begin{tabular}{|c|c|c|}
\hline & S-GMM & D-GMM \\
\hline \multirow[t]{2}{*}{ Growth (-1) } & $0.884^{* * *}$ & $0.350^{* * *}$ \\
\hline & $(0.009)$ & $(0.138)$ \\
\hline \multirow[t]{2}{*}{ Public investment } & $28.772^{\star * \star}$ & $206.204^{* *}$ \\
\hline & $(3.439)$ & (94.393) \\
\hline \multirow[t]{2}{*}{ Inflation } & $0.079^{* * *}$ & $2.315^{\star \star}$ \\
\hline & $(0.009)$ & $(1.123)$ \\
\hline \multirow[t]{2}{*}{ Public investment*inflation } & $-0.061^{* * *}$ & $-0.436^{* *}$ \\
\hline & $(0.007)$ & $(0.199)$ \\
\hline \multirow[t]{2}{*}{ Private investment } & $0.533^{* \star *}$ & -0.178 \\
\hline & $(0.064)$ & $(0.463)$ \\
\hline \multirow[t]{2}{*}{ Recurrent expenditure } & $-0.528^{* * *}$ & $-2.196^{* * *}$ \\
\hline & $(0.082)$ & $(0.671)$ \\
\hline \multirow[t]{2}{*}{ Labor force } & -0.044 & $3.254^{* * *}$ \\
\hline & $(0.090)$ & $(0.722)$ \\
\hline \multirow[t]{2}{*}{ Infrastructure } & 0.0008 & -0.002 \\
\hline & $(0.002)$ & $(0.029)$ \\
\hline \multirow[t]{2}{*}{ Trade openness } & $0.021^{* * *}$ & $0.318^{* *}$ \\
\hline & $(0.001)$ & $(0.124)$ \\
\hline Instrument & 40 & 18 \\
\hline Province/Observation & $52 / 416$ & $52 / 364$ \\
\hline Sargan test & 0.292 & 0.591 \\
\hline Hansen test & 0.112 & 0.249 \\
\hline $\mathrm{AR}(2)$ test & 0.970 & 0.112 \\
\hline
\end{tabular}

Note: ${ }^{* * *},{ }^{* *}$ and ${ }^{*}$ denote significance at $1 \%, 5 \%$ and $10 \%$ respectively

Source: Stata software 


\subsection{Robustness check by D-GMM}

In order to check the robustness of S-GMM estimates, we re-estimate Eq. (9) and Eq. (11) using D-GMM. The corresponding results are shown in Table 3 and Table 4. Consistent with D-GMM estimates, we find inflation promotes public investment (Table 3). Similarly, public investment and inflation promote economic growth, but their interaction term reduces it (Table 4). These findings are confirmed by battery of diagnostic tests shown at the bottom of Table 3 and Table 4 (Sargan, Hansen and Arellano-Bond AR(2) tests), indicating that DGMM estimates are largely reliable.

\section{Conclusion and policy implications}

As an emerging economy with a relatively high level of public investment, Vietnam is facing some macro-economic challenges to stabilize and promote economic growth. Does inflation affect the public investment - growth relationship in Vietnam? We find the answer by using S-GMM for a balanced panel data of 52 provinces during the period of 2005-2014. The contribution of the paper to the literature is to investigate the role of inflation in the public investment - growth relationship. Therefore, the empirical results not only contribute to our understanding of the role of inflation in the public investment - growth relationship, but also suggest some important policy implications to the governments in developing countries, specifically the Vietnam government.

In line with previous literature, our study indicates public investment and inflation enhance economic growth, but their interaction term impedes it. From these findings, we emphasize that any research on the public investment - growth relationship in Vietnam without taking the role of inflation into account is likely to be a shortcoming. In addition, the empirical results show private investment, government recurrent expenditure, and trade openness are the significant determinants of growth.

The findings provide a case for more prudence in design, formulation and implementation of policies relating to public investment in developing countries. The implication is that inflation plays a crucial role in the public investment-growth relationship, and the control of inflation positively contributes to this relationship. Therefore, governments in developing countries, specifically the Vietnam government, should prudently control inflation to provide a conducive environment for contribution of public capital spending and improving economic growth. For future research, it will be useful to look at the role of inflation in the effects of different public capital spending by sectors on economic growth 


\section{References}

Abiad, M. A., Furceri, D., \& Topalova, P. (2016). The macroeconomic effects of public investment: Evidence from advanced economies. Journal of Macroeconomics, 50, 224-240.

Andrade, J. S., Duarte, A. P. (2016). Crowding-in and crowding-out effects of public investments in the Portuguese economy. International Review of Applied Economics, 30(4), 488-506.

Arellano, M., \& Bover, O. (1995). Another look at the instrumental variable estimation of error-components models. Journal of econometrics, 68(91), 29-51.

Arellano, M., \& Bond, S. (1991). Some tests of specification for panel data: Monte Carlo evidence and an application to employment equations. The Review of Economic Studies, 58(2), 277-297.

Asiedu, E. (2002). On the determinants of foreign direct investment to developing countries: Is Africa different? World development, 30(1), 107-119.

Baglan, D., \& Yoldas, E. (2014). Non-linearity in the inflation-growth relationship in developing economies: Evidence from a semiparametric panel model. Economics Letters, 125(1), 93-96.

Barro, R. J., Sala-I-Martin, X., Blanchard, O. J. \& Hall, R. E. (1991). Convergence across states and regions. Brookings Papers on Economic Activity, 1991(1), 107-182.

Barro, R. J., \& Sala-I-Martin, X. (2004). Economic growth (2nd Ed.). Cambridge, Massachusetts: The MIT Press.

Belloc, M., \& Vertova, P. (2006). Public investment and economic performance in highly indebted poor countries: An empirical assessment. International Review of Applied Economics, 20(2), 151-170.

Bick, A. (2010). Threshold effects of inflation on economic growth in developing countries. Economics Letters, 108(2), 126-129.

Bissoon, O. (2012). Can better institutions attract more foreign direct investment (FDI)? Evidence from developing countries. International Research Journal of Finance $\mathcal{E}$ Economics, 82, 142-158.

Bittencourt, M. (2012). Inflation and economic growth in Latin America: Some panel timeseries evidence. Economic Modelling, 29(2), 333-340.

Bittencourt, M., Van Eyden, R., \& Seleteng, M. (2015). Inflation and economic growth: Evidence from the Southern African development community. South African Journal of Economics, 83(3), 411-424.

Blankenau, W. F., \& Simpson, N. B. (2004). Public education expenditures and growth. Journal of Development Economics, 73(2), 583-605. 
Bleaney, M., Gemmell, N., \& Kneller, R. (2001). Testing the endogenous growth model: Public expenditure, taxation, and growth over the long run. Canadian Journal of Economics, 34(1), 36-57.

Blundell, R., \& Bond, S. (1998). Initial conditions and moment restrictions in dynamic panel data models. Journal of Econometrics, 87(1), 115-143.

Bose, N., Haque, M. E., \& Osborn, D. R. (2007). Public expenditure and economic growth: A disaggregated analysis for developing countries. The Manchester School, 75(5), 533-556.

Du, J., Lu, Y., \& Tao, Z. (2008). Economic institutions and FDI location choice: Evidence from US multinationals in China. Journal of Comparative Economics, 36(3), 412-429.

Ferreira, P. C. (1999). Inflationary financing of public investment and economic growth. Journal of Economic Dynamics and Control, 23(4), 539-563.

Friedman, M. (1977). Nobel lecture: Inflation and unemployment. The Journal of Political Economy, 85(3), 451-472.

Ghura, M. D. (1997). Private investment and endogenous growth: Evidence from Cameroon (No. 97-165). International Monetary Fund.

Gillman, M., Harris, M. N., \& Mátyás, L. (2004). Inflation and growth: Explaining a negative effect. Empirical Economics, 29(1), 149-167.

Grossman, G. M., \& Helpman, E. (1991). Trade, knowledge spillovers, and growth. European Economic Review, 35(2), 517-526.

Hefner, F. L., \& Burson, T. E. (1990). The determinants of regional infrastructure spending. Regional Science Perspectives, 22, 19-26.

Holtz-Eakin, D., Newey, W., \& Rosen, H. S. (1998). Estimating vector autoregressions with panel data. Econometrica: Journal of the Econometric Society, 56(6), 1371-1395.

Jin, J., \& Zou, H. (2005). Fiscal decentralization, revenue and expenditure assignments, and growth in China. Journal of Asian Economics, 16(6), 1047-1064.

Judson, R. A., \& Owen, A. L. (1999). Estimating dynamic panel data models: A guide for macroeconomists. Economics Letters, 651, 9-15.

Kataoka, M. (2005). Effect of public investment on the regional economies in postwar Japan. Review of Urban E Regional Development Studies, 17(2), 115-139.

Khan, M. S., \& Ssnhadji, A. S. (2001). Threshold effects in the relationship between inflation and growth. IMF Staff Papers, 48(1), 1-21.

Khan, Y., Tariq, M., \& Sasaki, K. (2001). Roles of public capital in Pakistan's economy: Productivity, investment and growth analysis. Review of Urban \& Regional Development Studies, 13(2), 143-162.

Kremer, S., Bick, A., \& Nautz, D. (2013). Inflation and growth: New evidence from a dynamic panel threshold analysis. Empirical Economics, 44(2), 861-878.

Kuzmina, O., Volchkova, N., \& Zueva, T. (2014). Foreign direct investment and governance 
quality in Russia. Journal of Comparative Economics, 42(4), 874-891.

López-Villavicencio, A., \& Mignon, V. (2011). On the impact of inflation on output growth: Does the level of inflation matter? Journal of Macroeconomics, 33(3), 455-464.

Lucas, R. E. (1988). On the mechanics of economic development. Journal of Monetary Economics, 22(1), 3-42.

Makki, S. S., \& Somwaru, A. (2004). Impact of foreign direct investment and trade on economic growth: Evidence from developing countries. American Journal of Agricultural Economics, 86(3), 795-801.

Mallik, G., \& Chowdhury, A. (2001). Inflation and economic growth: Evidence from four south Asian countries. Asia-Pacific Development Journal, 8(1), 123-135.

Mittnik, S., \& Neumann, T. (2001). Dynamic effects of public investment: Vector autoregressive evidence from six industrialized countries. Empirical Economics, 26, 429446.

Milbourne, R., Otto, G., \& Voss, G. (2003). Public investment and economic growth. Applied Economics, 35(5), 527-540.

Murty, K. N., \& Soumya, A. (2007). Effects of public investment on growth and poverty. Economic and Political Weekly, 42(1), 47-59.

Omay, T., \& Öznur Kan, E. (2010). Re-examining the threshold effects in the inflationgrowth nexus with cross-sectionally dependent non-linear panel: Evidence from six industrialized economies. Economic Modelling, 27(5), 996-1005.

Ramirez, M. D., \& Nazmi, N. (2003). Public investment and economic growth in Latin America: An empirical test. Review of Development Economics, 7(1), 115-126.

Risso, W. A., \& Carrera, E. J. S. (2009). Inflation and Mexican economic growth: Long-run relation and threshold effects. Journal of Financial Economic Policy, 1(3), 246-263.

Rodríguez-Pose, A., Psycharis, Y., \& Tselios, V. (2012). Public investment and regional growth and convergence: Evidence from Greece. Papers in Regional Science, 91(3), 543568.

Romer, P. M. (1986). Increasing returns and long-run growth. The Journal of Political Economy, 94(5), 1002-1037.

Roodman, D. (2006). How to do xtabond2: An introduction to difference and system GMM in Stata. The Stata Journal, 9(1), 86-136.

Thanh, S. D. (2015). Threshold effects of inflation on growth in the ASEAN-5 countries: A panel smooth transition regression approach. Journal of Economics Finance and Administrative Science, 20(38), 41-48.

Tondl, G. (2001). Convergence after divergence? Regional growth in Europe. New York, SpringerVerlag Wien New York.

To, T. T. (2012). Public investment overwhelmed private investment: From the perspective of the 
empirical model VECM (in Vietnamese). University of Economics, Vietnam National University, Hanoi.

Vaona, A., \& Schiavo, S. (2007). Nonparametric and semiparametric evidence on the longrun effects of inflation on growth. Economics Letters, 94(3), 452-458.

Vinayagathasan, T. (2013). Inflation and economic growth: A dynamic panel threshold analysis for Asian economies. Journal of Asian Economics, 26, 31-41.

Yanikkaya, H. (2003). Trade openness and economic growth: A cross-country empirical investigation. Journal of Development Economics, 72(1), 57-89. 